\title{
The Generation of Neuronal Heterogeneity in a Rat Sensory Ganglion
}

\author{
Alison K. Hall, Xingbin Ai, Georgia E. Hickman, Sally E. MacPhedran, Constance O. Nduaguba, and \\ Christie P. Robertson \\ Department of Neurosciences, Case Western Reserve University, School of Medicine, Cleveland, Ohio 44106-4975
}

Adult sensory neurons differ chemically, morphologically, and functionally, but the factors that generate their diversity remain unclear. For example, neuropeptides are generally found in small neurons, whereas abundant neurofilament is common in large neurons. Neurons containing the neuropeptides calcitonin gene-related peptide (CGRP) or substance $P$ were quantified using immunohistochemistry in rat lumbar dorsal root ganglion (DRG) at times before and after sensory neurons contact central and peripheral targets in vivo. No neurons in the newly formed DRG expressed neuropeptide or neuropeptide mRNA, but neuropeptides were detectable about the time that axons connect with peripheral targets. To determine the requirement for target in neuropeptide regulation, embryonic DRG neurons were isolated at times before central and peripheral connections had formed, placed in culture, and immunocytochemically assayed for CGRP and substance P. Cultured neurons expressed neuropeptides with a time course and in proportions similar to those in vivo. Thus, some neurons in the embryonic
DRG seem to be intrinsically specified to later express CGRP and substance $P$. The percentage of CGRP-immunoreactive neurons was not changed by cell density, non-neuronal cells, neurotrophins in addition to nerve growth factor (NGF), or antibody inactivation of neurotrophin-3 in the presence of NGF. To test the role of extrinsic cues on CGRP expression, DRG neurons were co-cultured with potential target tissues. Coculture with a rat epidermal or smooth muscle cell line increased the proportion of CGRP-containing neurons, whereas primary skeletal muscle and 3T3 cells had no effects. Thus, multiple appropriate sensory neuron phenotypes arise in a regulated fashion in cultured neurons isolated before target connections have formed, and some candidate target tissues can modulate that intrinsic expression pattern.

Key words: neuropeptides; substance $P$; calcitonin generelated peptide; neurofilament; nociceptive; sensory ganglion; target tissue; skin; neurotrophin
A striking feature of the adult vertebrate sensory nervous system is the diversity of neuronal cell types that perform together to maintain homeostasis and convey information about the environment. During development, specific neurons must be generated in appropriate locations and connect discretely to both peripheral targets and the CNS for functional integrity. Thus, it is important to understand not only how the phenotype is generated but also how neurons match targets. This study examines the developmental regulation of sensory neurons containing calcitonin generelated peptide (CGRP) that predominantly contact visceral and cutaneous peripheral target end organs in vivo.

Adult rat sensory neurons can express neuromodulatory neuropeptides, but the factors that regulate their initial expression remain unknown. Cutaneous afferents appear in rat proximal hindlimb on embryonic days 14-15 (E14-E15) and in skin of distal toes at E16-E17 (Reynolds et al., 1991; Mirnics and Koerber, 1995). These fibers are functional slightly later, beginning at E17 (Saito, 1979; Kudo and Yamada, 1985; Fitzgerald, 1987; Kucera et al., 1988; Fitzgerald, 1991). Neuropeptides appear

Received Dec. 4, 1996; revised Jan. 16, 1997; accepted Feb. 6, 1997.

This study was supported by the National Science Foundation (IBN93-10511) and National Institutes of Health (NS-30842, with C.O.N. supported by a supplement for underrepresented minorities, and NS-23678). We thank Drs. Story C. Landis and David Katz for helpful comments and suggestions on this manuscript.

Correspondence should be addressed to Alison K. Hall at the above address.

Georgia E. Hickman's present address: Department of Molecular Genetics, Ohio State University, Columbus, OH 43210.

Christie P. Robertson's current address: Department of Neuroscience, University of Washington, Seattle, WA 98195.

Copyright (C) 1997 Society for Neuroscience $0270-6474 / 97 / 172775-10 \$ 05.00 / 0$ around the time of peripheral target functional contacts (E18E19) (Kessler and Black, 1981; Senba et al., 1982), suggesting that target interactions could influence sensory neuronal phenotype.

Neuropeptide expression, neurofilament content, and perikaryal size characterize broad classes of dorsal root ganglion (DRG) neurons with generally segregated functions. Neuropeptides are often found in small DRG neurons that can innervate skin and viscera, whereas abundant neurofilament expression is characteristic of large neurons that innervate muscle spindles (Lawson et al., 1984; Perry et al., 1991). The neuropeptides CGRP and substance $P$ are usually found in small neurons but can be contained in sensory neurons of varied sizes (Gibson et al., 1984; Lee et al., 1985; Skofitsch and Jacobowitz, 1985; Gibbins et al., 1987; Marti et al., 1987; Molander et al., 1987; McCarthy and Lawson, 1989, 1990; O'Brien et al., 1989). The coexistence of particular peptides in specific subpopulations of DRG neurons is related to peripheral targets. For example, there is a strong correlation between pain detection and localization of substance P or CGRP (Lembeck and Gamse, 1982; Hunt and Rossi, 1985; Scott, 1992). CGRP is localized in polymodal nociceptors, is a potent vasodilator, and may play a role in inflammation (Holzer, 1988; Scott, 1992).

To elucidate the mechanisms that contribute to sensory neuron phenotype, the development of major classes of sensory neurons was compared in vivo and in a tissue culture system, without and with target tissues. The proportion of neurons that expressed CGRP, substance P, or neurofilament was determined by immunohistochemistry in tissue sections of rat lumbar DRG from ages E14.5 to adult. DRG neurons isolated at a time before sensory 
neurons contact central and peripheral targets in vivo were then maintained in culture, and these broad classes of sensory phenotypes were assayed immunocytochemically. The expression of these two neuropeptides was remarkably similar in vivo and in vitro.

\section{MATERIALS AND METHODS}

Sprague Dawley rats were obtained from Zivic Miller (Zelienople, PA) and staged by embryonic day according to Christie, 1962. Animals were anesthetized with ethyl ether before perfusion and were euthanized by $\mathrm{CO}_{2}$ inhalation before tissue was harvested.

Immunohistochemistry. Postnatal and adult rats were perfused with $4 \%$ paraformaldehyde/O.1 M phosphate buffer, $\mathrm{pH} 7.4$, and tissues were post-fixed for $1 \mathrm{hr}$. Embryo blocks that included the lower trunk were immersed in the same fixative for $1 \mathrm{hr}$. Tissues were placed in $30 \%$ sucrose $/ 0.1 \mathrm{M}$ phosphate buffer at $4^{\circ} \mathrm{C}$ overnight for cryoprotection. Ten micrometer transverse sections containing L4 and L5 DRG were collected on gelatin-subbed slides and stored at $-20^{\circ} \mathrm{C}$ until use. Sections $100-200 \mu \mathrm{m}$ apart were reacted with antibodies, and only neurons with a visible nucleus were quantified. Tissue sections were rinsed in PBS, preincubated in dilution buffer $(10 \mathrm{mM}$ phosphate buffer, $0.3 \%$ Triton X-100, $0.5 \mathrm{~m}$ sodium chloride, $20 \mathrm{gm} / 1 \mathrm{BSA}, 15 \mathrm{~mm}$ sodium azide) for $1 \mathrm{hr}$, and incubated in primary antibody in dilution buffer overnight at room temperature [dilutions included substance $\mathrm{P}$ at 1:500, CGRP at 1:400, neuron-specific tubulin at 1:100 dilution, neurofilament-medium (NF-M) at 1:40 dilution, and NF-M-PO ${ }_{4}$ at 1:500]. After they were washed, tissue sections were incubated for $2 \mathrm{hr}$ at room temperature in fluorescenated secondary antibody in dilution buffer (goat anti-mouse $\mathrm{IgG}$ or goat anti-rabbit IgG; Cappel, Organon Teknica, or Antibodies, Inc.). Secondary antibodies were tested for reactivity with inappropriate primary antibodies and were species-specific (data not shown). For double-label immunohistochemistry, a cocktail of primary antibodies followed later by second antibodies was used. After they were washed, sections were mounted in 2\% n-propyl gallate in 1:1 PBS/glycerol. The omission of primary antibodies resulted in "background" levels of second antibody binding; any reactivity more intense than this background level was considered positive reactivity.

Cell cultures and immunocytochemistry. E14.5 and E12.5 DRG were dissociated using $5 \mathrm{mg} / \mathrm{ml}$ dispase (Boehringer Mannheim, Indianapolis, IN) in HBSS (Life Technologies, Gaithersburg, MD). Neurons were plated on polylysine (Sigma, St. Louis, MO) and laminin (BTI). In most cases, $\sim 15,000$ E14.5 DRG cells were plated in a 24-well. Growth medium for E14.5 DRG consisted of $\mathrm{L} 15-\mathrm{CO}_{2}$ with $5 \%$ rat serum (RS) and either nerve growth factor (NGF) alone ( $25 \mathrm{ng} / \mathrm{ml}$; Austral) or NGF with brain-derived neurotrophic factor (BDNF) and neurotrophin-3 (NT3) $(10 \mathrm{ng} / \mathrm{ml}$ each; R \& D Systems, Minneapolis, MN) added. Growth medium for E12.5 DRG included $\mathrm{L} 15-\mathrm{CO}_{2} / 5 \% \mathrm{RS} /$ Mito supplement (Collaborative Research, Bedford, MA), $50 \mathrm{~mm} \mathrm{KCl,} 25 \mathrm{ng} / \mathrm{ml} \mathrm{NGF}, 10$ $\mathrm{ng} / \mathrm{ml} \mathrm{BDNF}$, and $10 \mathrm{ng} / \mathrm{ml}$ NT3. Neurons were quantified by counting a strip representing $10 \%$ of the well area in 96 wells for survival assays, or a strip representing $5 \%$ of the area of $12 \mathrm{~mm}$ coverslips. The number of neurons at 24 or $48 \mathrm{hr}$ was used as the starting value for neuron survival studies. Neurons were identified morphologically by their phase-bright cell bodies and bipolar neurites. To determine the cell body diameter of E14.5 neurons cultured for 9 days, photographs of unselected strips of cells representing more than 100 cells/coverslip were prepared. The perikaryal diameter in the longest axis and the orthogonal axis were measured and used to calculate the mean neuron cell body cross-sectional area. In some cultures, $10^{-5} \mathrm{M}$ cytosine arabinoside was added to the cultures for the second $24 \mathrm{hr}$. After an additional $24 \mathrm{hr}$, the cultures were washed with growth medium and subsequently maintained as usual.

To test the role of target cells, several cell lines or primary cells were co-cultured with DRG neurons. Rat embryonic skin cells (ATCC 1213), 3 T3 cells, smooth muscle cell line (ATCC 1444), or primary hindlimb skeletal muscle cells were acclimated to $\mathrm{L} 15-\mathrm{CO}_{2}$ with $5 \%$ RS before use. The target cells survived best on collagen substrates, and their proliferation was controlled by a single cobalt irradiation. Approximately 70,000 target cells were plated per $12 \mathrm{~mm}$ coverslip, and approximately 15,000 dissociated E14.5 DRG cells were added to the monolayer the next day. No gross differences were seen in the number of neurons that initially attached to these monolayers. The cultures were maintained for $9 \mathrm{~d}$, a period in which CGRP expression becomes detectable, and then fixed and reacted with CGRP and neuron-specific tubulin antibodies. In each case, the continued presence of a monolayer of added cells at the end of the culture period was confirmed with cell type-specific antibodies (fibronectin for $3 \mathrm{~T} 3$ cells, smooth muscle actin for smooth muscle, cytokeratin for skin, and skeletal muscle myosin for skeletal muscle; data not shown).

For immunocytochemistry, cells were immersed in $4 \%$ paraformalde-

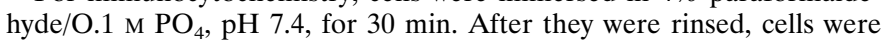
incubated with antibody to substance P (1:500) or CGRP (1:500) in PBS; $0.2 \%$ Triton $\mathrm{X}-100$ overnight at $4^{\circ} \mathrm{C}$, washed, and incubated with fluorescenated secondary antibodies (1:200, $2 \mathrm{hr}$ at room temperature). Cells were then reacted with neuron-specific tubulin $(1: 200)$ or NF-M or NF-H- $\mathrm{PO}_{4}(1: 40$ and 1:500, respectively) for $30 \mathrm{~min}$ at room temperature, washed, and incubated with fluorescenated secondary antibody for $30 \mathrm{~min}$ at room temperature. The number of neurons that expressed neuropeptide was determined by counting at least 200 neuron-specific tubulinimmunoreactive (IR) neurons per coverslip, with at least two coverslips per experiment in at least three experiments. The means obtained were compared by unpaired $t$ test. E12.5 DRG cultures were assayed for CGRP expression after $10 \mathrm{~d}$ by visualizing antibody binding with peroxidase-linked second antibody and a diaminobenzidine substrate.

Antibodies. Several antibodies against neuronal epitopes were used, including monoclonal antibody to neuron-specific tubulin (gift of A. Frankfurter, University of Virginia), monoclonal antibody to NF-M (Sigma), and monoclonal antibody to NF-M-PO of Pennsylvania). Antisera to substance P (Incstar) and CGRP (Amersham, Arlington Heights, IL) were used to detect neuropeptides. Specificity of these antibodies was assayed in peptide-blocking control studies. Substance P or CGRP (each at $25 \mu \mathrm{g} / \mathrm{ml}$; Peninsula) was incubated with appropriate diluted antisera at $4^{\circ} \mathrm{C}$ overnight and applied to DRG tissue sections as usual, followed by fluorescent secondary antibody. In the presence of blocking peptide, no specific fluorescence was detected (data not shown). In some experiments, function-blocking antibody to NT3 was used $(50 \mathrm{ng} / \mathrm{ml}$; Austral).

CGRP $m R N A$ detection. RNA from E12, E14, and E18 lumbar DRG was extracted with RNAzol (Tel-Test). Reverse transcription (RT) was performed using $\sim 5 \mu \mathrm{g}$ of RNA with $200 \mathrm{U}$ of reverse transcriptase (Superscript II, Life Technologies) in a final volume of $20 \mu \mathrm{l}$ of RT solution $\left(20 \mathrm{~mm}\right.$ Tris, $\mathrm{pH} 8.3,50 \mathrm{~mm} \mathrm{KCl}, 5 \mathrm{~mm} \mathrm{MgCl}_{2}, 10 \mathrm{~mm}$ dithiothreitol, $4 \mathrm{~mm}$ sodium pyrophosphate, $1.25 \mathrm{~mm} \mathrm{dNTP}$, and $50 \mu \mathrm{g} / \mathrm{ml}$ oligo $\mathrm{dT})$ at about $42^{\circ} \mathrm{C}$ for $1 \mathrm{hr}$. The RNA was treated with DNase I ( $1 \mathrm{U} / \mu \mathrm{l}$ for $15 \mathrm{~min}$ at $37^{\circ} \mathrm{C}$, followed by inactivation for $10 \mathrm{~min}$ at $100^{\circ} \mathrm{C}$ ) to destroy any contaminating DNA before proceeding to RT. PCR amplification was performed by adding $10-100 \%$ of the RT sample to PCR buffer (Stratagene, La Jolla, CA) with $0.2 \mathrm{~mm}$ deoxynucleoside triphosphates, $50 \mathrm{pmol}$ of each primer, and $1 \mathrm{U} \mathrm{Taq}$ polymerase (Stratagene) in a total volume of $50 \mu$ l. Oligonucleotide primers were located in the common region for $\alpha$ and $\beta$ CGRP: 5'-AGA TCC TGC AAC ACC GCC AC- $3^{\prime}$ and 5'-CCA CAT TGG TGG GCA CAA AGT TG3-' and EF1 $\alpha$ oligonucleotides for RNA quantification: 5'-TTC ACT GCT CAG GTG ATC ATCC-3' and 5'-GGC AGC ATC ACC AGA TTT CAA GA-3'. Messenger for the stably expressed elongation factor $1 \alpha$ was subjected to the same RT-PCR procedures as a control for sample RNA. PCR cycles were performed in an automated thermal cycler (Perkin-Elmer, Emeryville, CA) with the following profile: denaturation $96^{\circ} \mathrm{C}$ for $1 \mathrm{~min}$, primer annealing at $55^{\circ} \mathrm{C}$ for $1 \mathrm{~min}$, primer extension at $72^{\circ} \mathrm{C}$ for $2 \mathrm{~min}$. PCR fragments were separated in a $2 \%$ agarose gel, stained with ethidium bromide, and visualized under ultraviolet light.

\section{RESULTS}

To begin to understand the cellular and molecular mechanisms that regulate the differentiation of major classes of sensory neurons, we assayed the development of neuropeptides in DRG in vivo and developed a tissue culture model system in which embryonic mammalian sensory neurons differentiate in vitro.

\section{CGRP and substance $P$ expression in lumbar DRG neurons increased with age in vivo}

To identify the onset of expression and the numbers of neurons that express CGRP or substance $\mathrm{P}$ during development, and because immunohistochemical analyses of peptide expression are highly dependent on the specific reagents used, the same peptide antisera were used for quantifying neuropeptide expression in vivo and in vitro. CGRP immunoreactivity was absent soon after ganglion formation, but the proportion of 

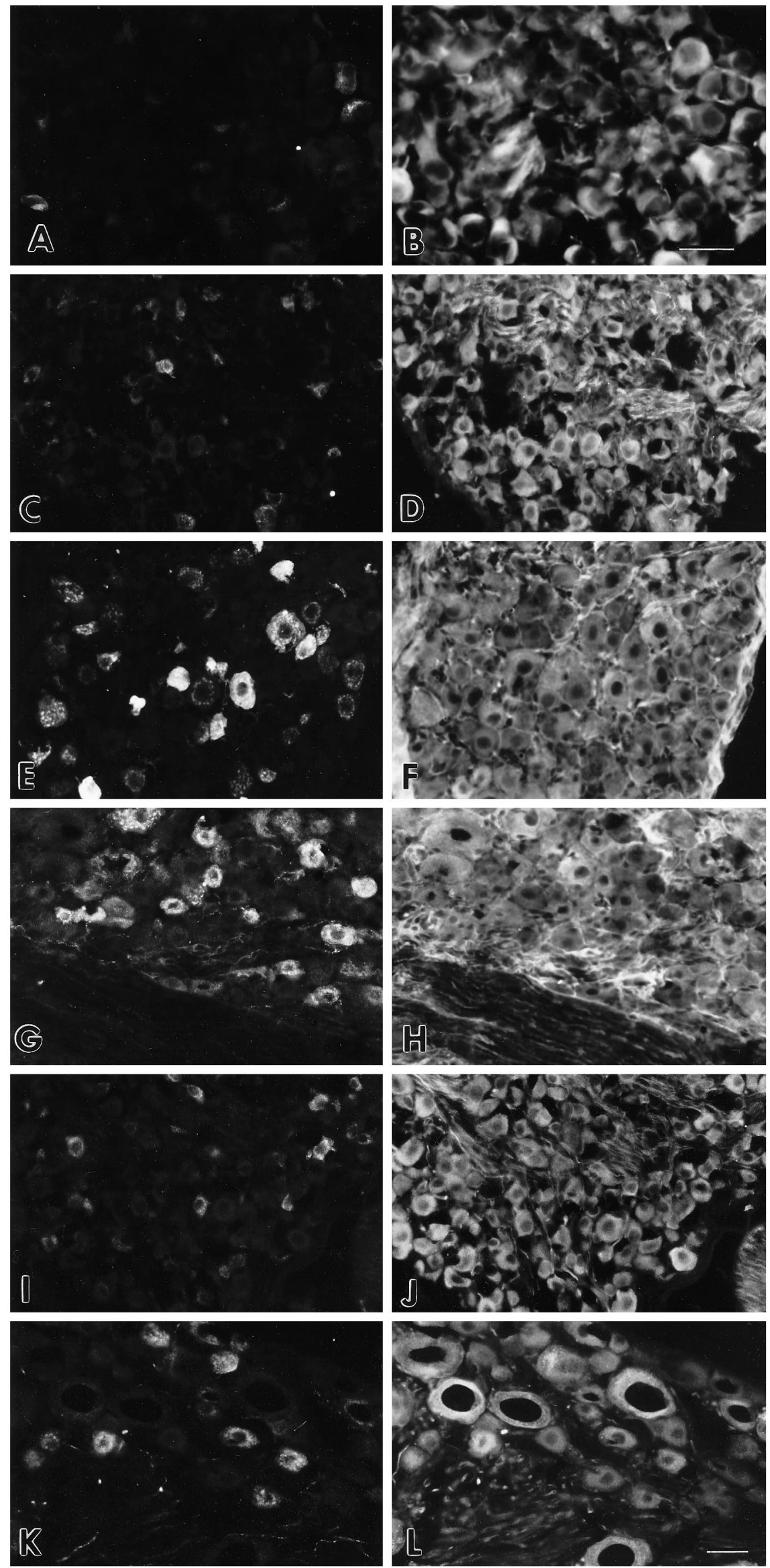

Figure 1. The number of CGRP- and substance P-IR neurons increased with development in vivo. CGRP-IR $(A, C, E, G)$ or substance P-IR $(I, K)$ neurons were identified with neuron-specific tubulin $(B, D, F, H, J, L)$ preceding and after periods of target contact in vivo. CGRP-IR neuronal perikarya were absent soon after gangliogenesis (E14.5, not shown). $A, B$, E18 DRG contain a few CGRP-IR neurons. $C$, $D$, Some neonatal DRG neurons were CGRP-IR. $E$, $F$, Many CGRP-IR neurons were present at P8. $G, H$, Adult DRG contained numerous CGRP-IR neuronal cell bodies and axonal processes. Similarly, substance P-IR neurons were detected in neonatal $(I, J)$ and adult $(K, L)$ DRG. Note that both neuropeptide immunoreactivities were predominantly detected in small neurons. Scale bars (shown in $B$ ): $A, B, 30 \mu \mathrm{m}$; (shown in $L$ ): $C-L, 40 \mu \mathrm{m}$. 


\section{DRG}

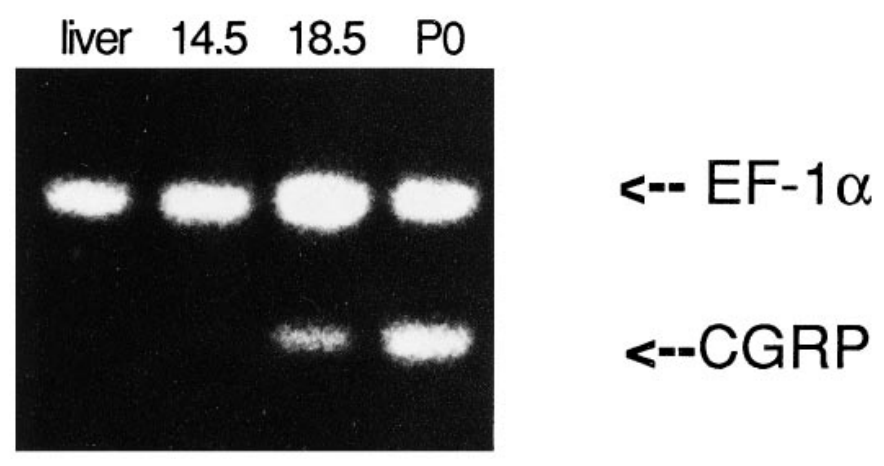

Figure 2. CGRP mRNA was detected in the DRG at the time that functional target connections form in vivo. RT-PCR was performed on total RNA from liver control tissue and DRG at E14.5, E18.5, and birth. A 106 basepair (bp) product for CGRP was expected. To control for the amount of RNA, a second transcript, elongation factor-1 mRNA was assayed in each sample (expected length, $182 \mathrm{bp}$ ). No CGRP mRNA was detected at E14.5. CGRP mRNA was detected at E18.5 and P0, times at which the peptide can also be detected immunocytochemically and when functional central and peripheral connections are present in vivo.

CGRP-IR neurons and the intensity of neuropeptide immunoreactivity increased with development (Figs. $1 A-H, 4)$. At E18.5, when many neurons have reached target tissues and responses to peripheral stimuli are detectable, a few neurons were CGRP-IR. Most DRG neurons have contacted both central and peripheral targets at birth, and CGRP immunoreactivity was localized to both neuronal cell bodies and axonal processes within the ganglion at postnatal day $0(\mathrm{P} 0)$. The number of substance P-IR neurons also increased with age (Fig. 1I-L). No neurons were substance P-IR at E14.5, and a few expressed substance $P$ at E19.5 (13.5\% \pm 1.9 SEM; 1462 neurons counted). Many substance P-IR neurons were present at birth $(22.7 \% \pm 2.0$ SEM; 1802 neurons $)$ and in the adult (22.7\% \pm 2.6 SEM; 4299 neurons counted); sections from one ganglion each from two animals at each age were quantified. As expected, both CGRP and substance P immunoreactivities were generally localized in smaller neurons and were present infrequently in large, neurofilament-IR neurons. These data on the proportion of adult DRG neurons with these neuropeptides were similar to those in other reports (Lee et al., 1985; Tuchscherer and Seybold, 1985; Kai-Kai et al., 1986; Boehmer et al., 1989; Noguchi et al., 1990).

The expression of CGRP mRNA (Fig. 2) was similar to CGRP peptide seen with immunohistochemistry. RT-PCR was performed on RNA from lumbar DRG at different embryonic ages. CGRP mRNA was not detected at E14.5, confirming our hypothesis that gene transcription had not occurred at this embryonic stage. As expected, CGRP mRNA was detected at E18.5 and P0, times at which the peptide can also be detected immunohistochemically.

\section{Neuropeptide- and neurofilament-containing DRG neurons developed in the absence of target tissues}

Sensory ganglia were harvested at E14.5, before CGRP mRNA or peptide were detectable and before functional peripheral target connections had occurred in vivo, and placed in tissue culture. Very few DRG neuroblasts incorporate DNA analogs at this stage ( $\sim 3 \%$ at E14.5 in vivo and in vitro) (Lawson et al., 1974; and data not shown). Because target tissues were absent, such environmental cues could be manipulated, and the intrinsic developmental capacity of embryonic sensory ganglia could be evaluated.

CGRP and neurofilament immunoreactivities were typically found in mutually exclusive neuronal populations in cultured DRG neurons (Fig. 3A). Neurofilament content can distinguish $\sim 40 \%$ of lumbar DRG neurons that often are of large diameter (Lawson et al., 1984; Lawson and Waddell, 1991; Perry et al., 1991). Two antibodies were used to assay neurofilament: one that recognizes the intermediate molecular weight isoform (NF-M) and a second that recognizes the high molecular weight isoform only when phosphorylated (NF-H- $\left.\mathrm{PO}_{4}\right)$, and similar results were obtained. After $9 \mathrm{~d}$ of culture in NGF + BDNF + NT3, subsets of neurons from E14.5 DRG were CGRP-IR $(16.6 \% \pm 1.91$ SEM), neurofilament $\mathrm{H}-\mathrm{PO}_{4}$-IR $(28.4 \% \pm 3.2 \mathrm{SEM})$, or NFM-IR $(46 \% \pm 3.4 \mathrm{SEM})$, but they rarely co-expressed CGRP and neurofilament (CGRP/NF-M, 2.8\% \pm 1.0; CGRP/NF-H- $\mathrm{PO}_{4}$, $0.53 \% \pm 0.24 \mathrm{SEM})$. There was no apparent grouping of neurons, and CGRP- and NF-IR neurons were intermingled. These data provide strong evidence that two major classes of DRG neurons develop with appropriate quantitative regulation in the absence of target tissues.

Although the biochemical differentiation of DRG neurons in culture was similar to DRG populations in vivo, in one respect, neuronal differentiation in these cultures differed from normal sensory development. When the neuronal perikaryal areas of cultured neurons were analyzed, unlike postnatal rat DRG neurons in vivo that seem to be made up of two populations representing both small and large neurons (Lawson and Waddell, 1991), DRG neurons in vitro appeared as a relatively uniform population (Fig. 3B).

\section{CGRP expression by cultured DRG neurons was temporally similar to that in vivo}

To understand whether CGRP expression by DRG neurons in vitro was temporally similar to the expression of this peptide in vivo, cultured DRG neurons were evaluated for CGRP immunoreactivity over time. CGRP expression was examined soon after plating when many neurons were extending axons $(1 \mathrm{~d})$, at intermediate times corresponding with the period of target contact in vivo $(3,6$, and $9 \mathrm{~d})$, and at a time equivalent to early postnatal stages when CGRP expression may have stabilized (12 d, similar to P4; parturition occurs on E22). As in vivo, CGRP immunoreactivity in vitro was absent from non-neuronal cells. No neurons at E14.5 + 1 were CGRP-IR (data not shown), but the proportion of neurons with detectable levels of this neuropeptide increased with time in culture (Fig. 4). Similarly, $\sim 25 \%$ of neurons in similar embryonic DRG cultures for $9 \mathrm{~d}$ developed substance P immunoreactivity (348/1048 neurons from five coverslips in two independent experiments). Because not all neurons become CGRP- or substance P-IR in the relatively homogeneous culture environment, it is likely that the neurons themselves differ intrinsically in some way that alters their subsequent CGRP and substance P expression. Because both CGRP and substance P developed with temporal and quantitative characteristics similar to those in vivo, only CGRP immunoreactivity was evaluated in subsequent assays.

In view of our finding that CGRP developed in the E14.5 DRG, when a few axons have grown into the proximal hindlimb (but are not yet responsive to stimuli), we sought to determine whether cells from younger DRG also had the capacity to make CGRP. At E12.5, many DRG neuron precursors are undergoing their final mitoses, and most have not extended peripheral processes (Law- 
A
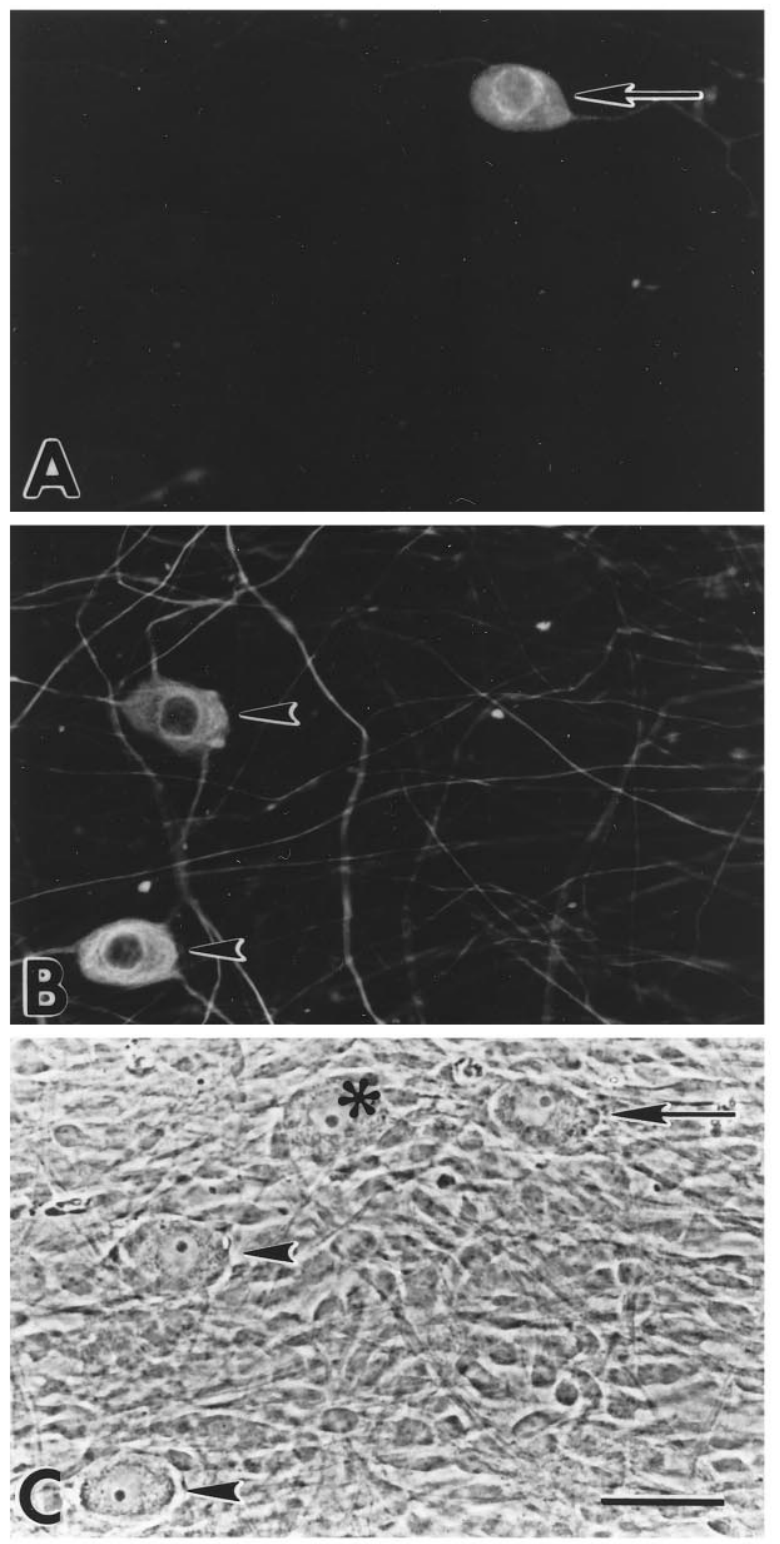

B

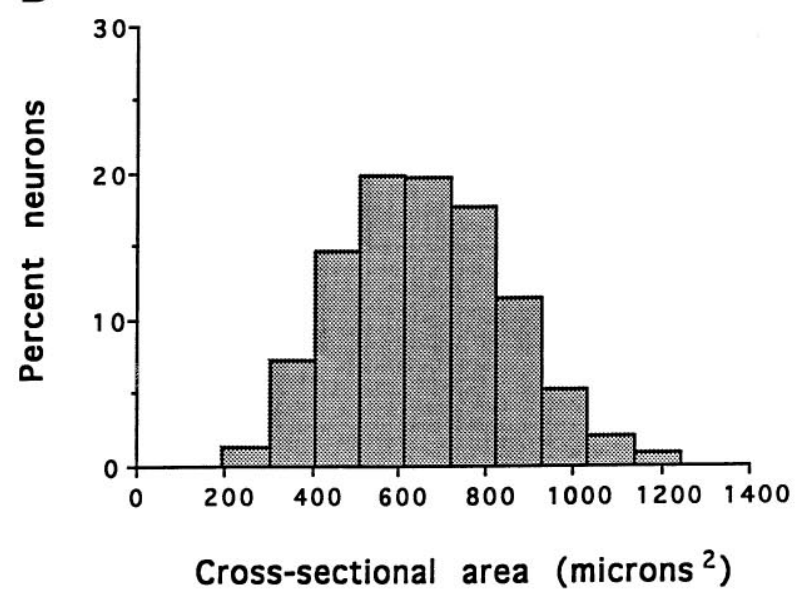

Figure 3. Discrete DRG neuronal phenotypes arose in culture. $A$, Two major DRG neuron classes were present in cultures without target tissues. son et al., 1974; Mirnics and Koerber, 1995). A subpopulation of DRG neurons/neuron precursors from E12.5 DRG developed CGRP expression at $9 \mathrm{~d}$ in culture (Fig. 5). These data provide strong support that a subpopulation of DRG neurons can regulate CGRP expression in the absence of target tissues. E12.5 DRG neuron precursors are proliferative in vivo and in vitro (Lawson et al., 1974; Memberg and Hall, 1995), making direct quantitation difficult. In addition, although neurons at this age can be maintained easily in short-term cultures (Memberg and Hall, 1995), they can be difficult to support for long periods of time and thus were not used for subsequent studies. These results suggest that the initial expression and regulation of CGRP is an intrinsic property of some neurons and does not depend on an intact DRG or peripheral target contact.

\section{General culture conditions did not regulate CGRP expression}

The percentage of CGRP-IR neurons was not altered by additional neurotrophic factors. At E14.5, NGF is a major short-term survival factor for rat DRG neurons, although at this stage NT3 and NT4 can also support similar populations of embryonic neurons for at least $2 \mathrm{~d}$ (Memberg and Hall, 1995). To test the possibility that neurotrophins affected long-term survival, neurons were counted by phase microscopy at $24 \mathrm{hr}, 48 \mathrm{hr}$, and $10 \mathrm{~d}$ in vitro in NGF or a cocktail of NGF + BDNF + NT3. Of neurons counted at $24 \mathrm{hr}, 90 \%$ were present at $48 \mathrm{hr}$, and two thirds were still present at $10 \mathrm{~d}$ of culture. No difference was seen in the number of neurons that survived $10 \mathrm{~d}$ in NGF or NGF + BDNF $+\mathrm{NT} 3(65 \% \pm 4$ or $71.5 \% \pm 2.6 \mathrm{SEM}$, respectively; unpaired $t$ test; $p=0.196)$. Thus, the culture conditions support the continued survival of the vast majority of DRG neurons initially plated, and BDNF and NT3 did not increase the number of surviving neurons in NGF. The percentage of CGRP-IR neurons that developed from E14.5 DRG after $9 \mathrm{~d}$ of culture in NGF alone was the same as that which developed in NGF + BDNF + NT3 $(22.2 \% \pm 1.97$ and $19.3 \% \pm 1.9 \mathrm{SEM}$, respectively; unpaired $t$ test; $p=0.31)$. One potential difficulty with this approach is that DRG neurons can themselves produce neurotrophins (Schecterson and Bothwell, 1992) that could already be acting in these cultures. To test the possibility that DRG cells make NT3 in these cultures and that the NT3 can affect CGRP expression, anti-NT3 was added to E14.5 DRG neurons in the presence of NGF and serum. Many E14.5 DRG neurons can be supported in short-term assays by NT3 (Memberg and Hall, 1995), and that survival can be blocked with antibody to NT3 (Fig. 6A). When DRG neurons were maintained in NGF for $8 \mathrm{~d}$, there was no change in the percentage of CGRP-IR neurons or the overall neuronal survival with the addition of anti-NT3 (Fig. 6B). Thus, it seems likely that DRG neurons possess some intrinsic capacity to regulate neuropeptide expression in these cultures and furthermore that BDNF and NT3

\footnotetext{
$\leftarrow$

To determine whether DRG cultures contained multiple neuronal cell types, E14.5 DRG neurons were grown in culture for $9 \mathrm{~d}$ and reacted with CGRP and NF-H-PO ${ }_{4}$ antibodies. CGRP $(A)$, neurofilament- $\mathrm{H}-\mathrm{PO}_{4}$ (CGRP), phase $(C)$ micrographs. Some neurons were CGRP-IR $(16 \%$; arrows), NF-H-PO $-\mathrm{IR}(28 \%$; arrowheads), doubly reactive $(0.5 \%$, not shown), or lacked both markers (55\%; asterisk). Scale bar, $40 \mu \mathrm{m} . B$, DRG neurons in vitro had a single size distribution. Neuronal perikaryal crosssectional areas of E14.5 DRG cultured for $10 \mathrm{~d}$ generally fall into one size class. The cell body diameters of neurons in NGF-containing cultures had an average perikaryal cross-sectional area of $658 \pm 7.9 \mu \mathrm{m}^{2}$ (583 neurons measured, four experiments).
} 


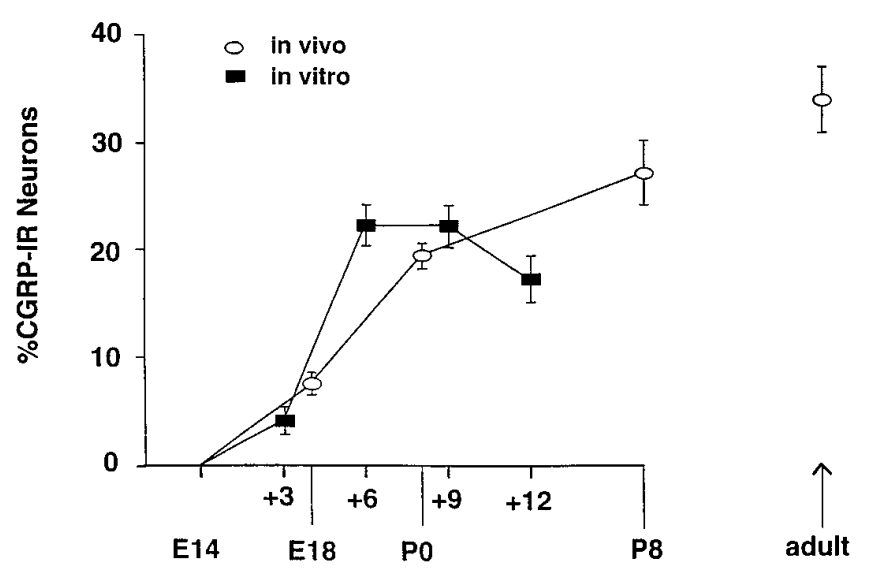

Age/ days in culture

Figure 4. Continued culture was sufficient to elicit changes in CGRP-IR neurons that occur in vivo. CGRP immunoreactivity in vivo was not apparent at E14.5, but the percentage of DRG neurons with the peptide rapidly increased from E18 $(7.6 \% \pm 1.0 \mathrm{SEM}$; three ganglia, nine sections) to birth ( $19.5 \% \pm 1.2 \mathrm{SEM}$; nine ganglia, 37 sections) to 1 week after birth, P8 (27.2\% $\pm 2.97 \mathrm{SEM}$; eight ganglia, 51 sections). The proportion of CGRP-IR neurons seemed stable after the first postnatal week, because adult values $(32.8 \% \pm 3.3 \mathrm{SEM}$; six ganglia, 52 sections) were not statistically different from $\mathrm{P} 8$ (unpaired $t$ test; $p=0.23$ ). The proportion of CGRP-IR neurons was similar in vitro and in vivo $(\mathrm{E} 14+3$ was similar to E18, and E14 + 6, + 9, and + 12 was similar to P0; unpaired $t$ test; $p<0.05$ ). Therefore, changes in the number of CGRP-IR neurons do not depend on an intact DRG or sustained contact with target tissues.

in addition to NGF do not affect the proportion of CGRP-IR neurons.

Initial ganglionic cell plating density and the presence of ganglionic non-neuronal cells did not affect the proportion of CGRP-IR neurons that developed in culture. DRG cultures established at 10,000, 20,000, or 40,000 cells per coverslip and grown for 1 week did not differ in the proportion of CGRP-IR neurons present $(20.3 \% \pm 3.8 \mathrm{SEM}, 21.4 \% \pm 3.1 \mathrm{SEM}$, and $19.9 \% \pm 3.4$ SEM, respectively). DRG cultures include neurons and nonneuronal satellite glia and fibroblastic cells. Non-neuronal cells can alter neuropeptides in peripheral ganglia (Patterson and
Chun, 1974; Nawa and Patterson, 1990; Sun et al., 1994). To test whether non-neuronal cells affected neuronal CGRP expression, some E14.5 DRG cultures were treated with antimitotic agents to remove non-neuronal cells on day 1 . Because the bulk of neuronal precursor division has ceased, this treatment effectively removed non-neuronal cells (Fig. 7). The overall survival of neurons for $9 \mathrm{~d}$ of culture was the same in control and cytosine arabinosidetreated cultures (unpaired $t$ test; $p=0.19$ ). Furthermore, the percentage of CGRP-IR neurons was the same in control and non-neuronal cell-free cultures (unpaired $t$ test; $p=0.18$ ). These data suggest that the number of CGRP-IR neurons is not affected by non-neuronal cells and provide further evidence that CGRP expression is an intrinsic property of some DRG neurons.

\section{Co-culture with target tissues can modulate the proportion of CGRP-IR neurons}

To test the effects of target tissues, dissociated E14.5 DRG were co-cultured in the presence of serum and NGF with cell lines or primary cells that approximate features of target tissues, and analyzed for CGRP expression. CGRP-IR neurons in vivo predominantly contact skin and visceral smooth muscle and, less frequently, skeletal muscle peripheral targets. When DRG neurons were co-cultured with 3 T3 or skeletal muscle cells, the percentage of CGRP-IR neurons that developed after $8 \mathrm{~d}$ was the same as that in control DRG cultures without added cells. By contrast, one physiologically appropriate target cell type, epidermal cells, increased the proportion of CGRP-IR neurons, without affecting overall neuronal survival compared with control (Fig. 8). Smooth muscle lines also increased the proportion of CGRP-IR neurons, but total neuronal survival was also decreased in this condition, suggesting that this tissue had selective effects. These data support the notion that some target tissues may possess factors that act to modulate CGRP expression and can increase the number of CGRP neurons above the permissive level obtained from DRG alone.

\section{DISCUSSION}

The proportion of CGRP- and substance P-IR neurons at several ages both in culture and in vivo was similar, suggesting that neurons did not require an intact DRG or connections with other tissues to regulate neuropeptides often expressed by nociceptive
Figure 5. A subpopulation of neurons from the neurogenic E12.5 DRG develop CGRP in vitro. Dissociated immature neurons from E12.5 lumbar DRG were grown for $10 \mathrm{~d}$ and assayed for CGRP expression. CGRP immunocytochemistry was performed with a horseradish peroxidase-linked second antibody and a visible diaminobenzidine substrate. CGRP was detected both in cell bodies and in processes of a small number of neurons (arrows). In first antibody ( $\left.N o 1^{\circ} \mathrm{Ab}\right)$ controls, CGRP antibody was omitted, but second antibody and diaminobenzidine reaction was applied. Scale bar, $50 \mu \mathrm{m}$.

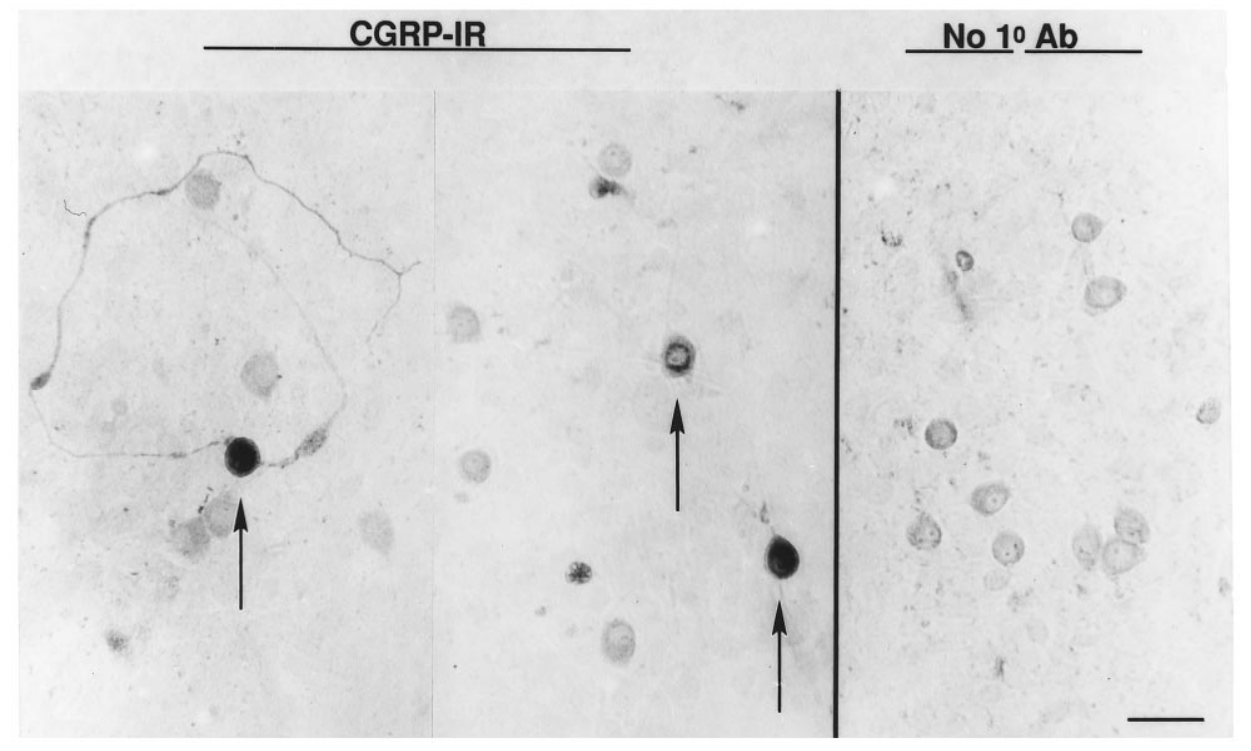




\section{A. Anti-NT3 Blocks NT3 Supported Survival}

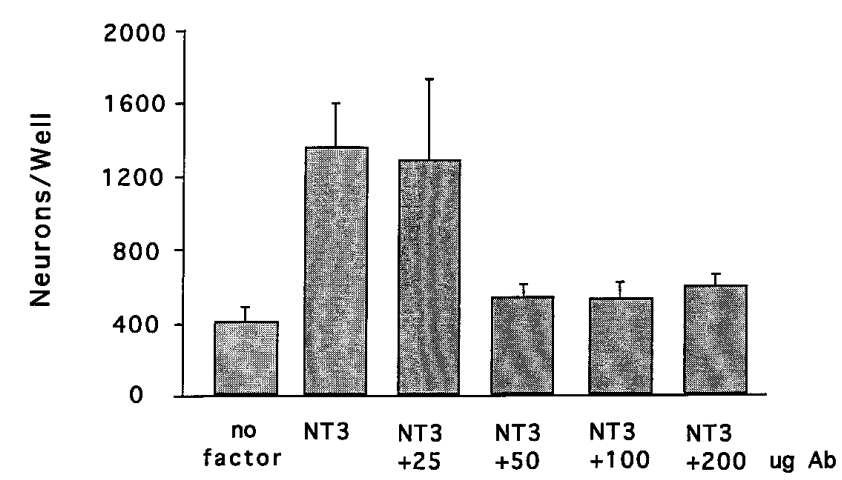

B. CGRP-IR Neurons at 8 days

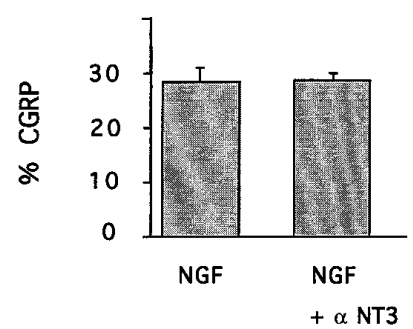

Figure 6. NT3 does not regulate the number of CGRP-IR neurons. $A$, Antibody dose-response. To determine the amount of antibody required to neutralize NT3 activity, a short-term neuronal survival assay was used. E14.5 DRG neurons were supported for $2 \mathrm{~d}$ by NT3 $(10 \mathrm{ng} / \mathrm{ml})$ and serum, and that survival activity was neutralized by the addition of 50,100 , or 200 $\mu \mathrm{g} / \mathrm{ml}$ anti-NT3. Twenty-five hundred cells, of which about half are neurons, were plated/96 well, with duplicates for each condition, and the experiments were performed twice. The mean number of neurons and SEM are shown. The lowest effective antibody concentration, $50 \mu \mathrm{g} / \mathrm{ml}$ of anti-NT3, was used for subsequent neutralization experiments in cocultures. B, Anti-NT3 had no effect on CGRP expression. Dissociated E14.5 DRG neurons were grown for $10 \mathrm{~d}$ in the growth medium containing RS and $25 \mathrm{ng} / \mathrm{ml} \mathrm{NGF}$ in the presence or absence of $50 \mu \mathrm{g} / \mathrm{ml}$ anti-NT3. Cells were processed for CGRP and neuron-specific tubulin immunocytochemistry. The percentage of CGRP-IR neurons and overall neuronal survival were equivalent in control and anti-NT3 conditions (unpaired $t$ test; $p>0.1$ ).

neurons. Similarly, neurofilament-IR neurons were also present in the absence of targets. These data suggest that two major DRG neuronal classes are phenotypically specified before contact with peripheral target tissues.

Peripheral target tissue contacts occur early in the rat hindlimb, but are unlikely to contribute to the quantitative appearance of neuropeptides observed in this study. DiI injection and growthassociated protein- 43 immunolabeling indicates some sensory afferents in the epidermis of the proximal hindlimb quite early, around E14, and some fibers reach the paw by E14.5-E15 (Reynolds et al., 1991; Coggeshall et al., 1994; Mirnics and Koerber, 1995), but it is not possible to quantify their prevalence. Physiological assays indicate that the first afferent terminals are formed later, at E17-E18 in hindlimb muscles (Kudo and Yamada, 1985; Kucera et al., 1988, 1989), and cutaneous plantar reflexes appear at E17.5 (Kudo and Yamada, 1985). It is unlikely that neurons have been influenced by cutaneous targets, because epidermis does not differentiate until E15-E17 (Kopan and Fuchs, 1989). The few processes that enter proximal leg early cannot quantita- tively account for the proportion of neurons that develop neuropeptides and neurofilament in culture. Many DRG axons at E14.5 have not contacted target tissues and thus could not have been "instructed." Similarly, spinal cord sensory innervation also occurs after the stage at which the DRG neurons were removed in these studies (Fitzgerald, 1987). Yet, cultures established from E14.5 ganglia at this age developed CGRP, substance P, and neurofilament expression in numbers of neurons appropriate for postnatal DRG. Furthermore, some neurons from E12.5 DRG developed CGRP expression in culture. Thus, it is clear that continued exposure to any potential target influences is not needed for CGRP expression.

Neurotrophins maintain sensory neuron survival during the period of cell death, and there is a good correlation between neurotrophin support and particular sensory functional subtypes, but it is unlikely that neurotrophins instruct some DRG neurons to become CGRP-IR. Neuronal death occurs in the rat DRG between E15 and P5, with a peak at E17-E19 (Coggeshall et al., 1994). NGF acting via its receptor trkA seems important for the survival of cutaneous and visceral afferents, whereas NT3 and its receptor trkC may be more important for muscle afferents (HoryLee et al., 1993; Crowley et al., 1994; Klein et al., 1994; McMahon et al., 1994; Smeyne et al., 1994). The embryonic sensory neurons assayed in the present studies, however, were obtained before segregation of neurotrophin responses occurred. In E14.5 rat lumbar DRG, the majority of neurons express most trk genes and polypeptides (McMahon et al., 1994; S. Memberg and A. Hall, unpublished observations), and neurons in this population respond to NGF, NT3, and NT4 almost equivalently for short-term survival (Memberg and Hall, 1995). Thus, although functional subtypes in mature animals show significant neurotrophin specificity, the embryonic neurons used in the present experiments do not display those subtypes. NGF is thought to regulate the level of neuropeptides already expressed by the neuron rather than to induce de novo expression of those neuropeptides (Kessler and Black, 1980; Otten et al., 1980; Kessler and Black, 1981; Adler et al., 1984; Lindsay and Harmar, 1989; Inaishi et al., 1992; Davies, 1994; Snider, 1994; Bothwell, 1995). Furthermore, although the NGF receptor trkA is downregulated in many small DRG neurons postnatally, the CGRP-IR neuronal phenotype is specified before the downregulation occurs (D. Molliver and W. Snider, personal communication). The present experiments provide strong evidence that neurotrophin activity does not establish neuronal phenotypic subtypes in the DRG.

Target tissue regulation of neuronal phenotype has been demonstrated in sympathetic neurons whose adrenergic or cholinergic neurotransmitter fate can be modified in vivo and in vitro by altering environmental cues (Patterson and Nawa, 1993; Schotzinger and Landis, 1994). Thus, sympathetic neurons can alter their neurotransmitter to match target tissue effectors. Some cranial sensory ganglia can be similarly modified (Fan and Katz, 1993). One indication of the plasticity of sympathetic neurons was obtained when non-neuronal cells were shown to alter their classical neurotransmitters and neuropeptides (Nawa and Patterson, 1990; Patterson and Chun, 1974; Sun et al., 1994). By contrast, nonneuronal cell removal did not affect the number of neuropeptidecontaining neurons in the present studies.

There is some evidence for phenotypic plasticity in sensory neurons. When embryonic amphibian sensory afferents were redirected, their central projections were appropriate for the new target (Frank and Westerfield, 1982; Smith and Frank, 1987, 1988). Rerouting of sensory afferents from muscle to skin alters 

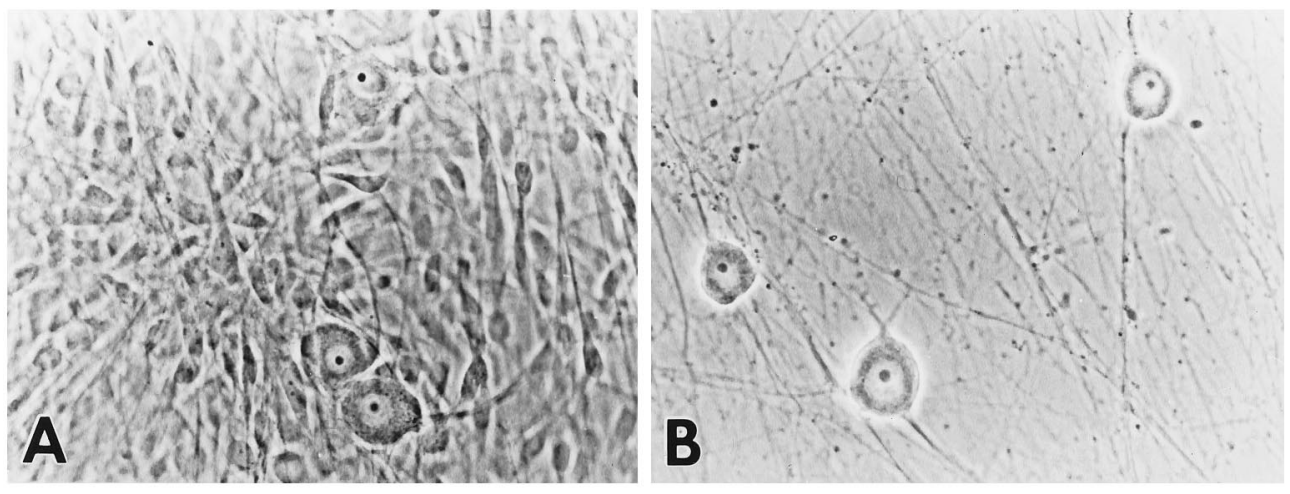

Figure 7. Non-neuronal cell removal did not affect the proportion of CGRP-IR neurons that developed from embryonic DRG. Dissociated E14.5 DRG neurons were untreated in control $(A, C)$ or incubated with $10^{-5} \mathrm{M}$ cytosine arabinoside $(B, D)$ for $24 \mathrm{hr}$ on day 1 to remove non-neuronal cells, and assayed for CGRP-IR neurons at day 9 in vitro. Antimitotic treatment removed non-neuronal cells from the cultures (compare $A$ and $B$ ), but did not alter the percentage of CGRP-IR neurons in the cultures (compare $C$ and $D)$. Scale bar, $30 \mu \mathrm{m}$.
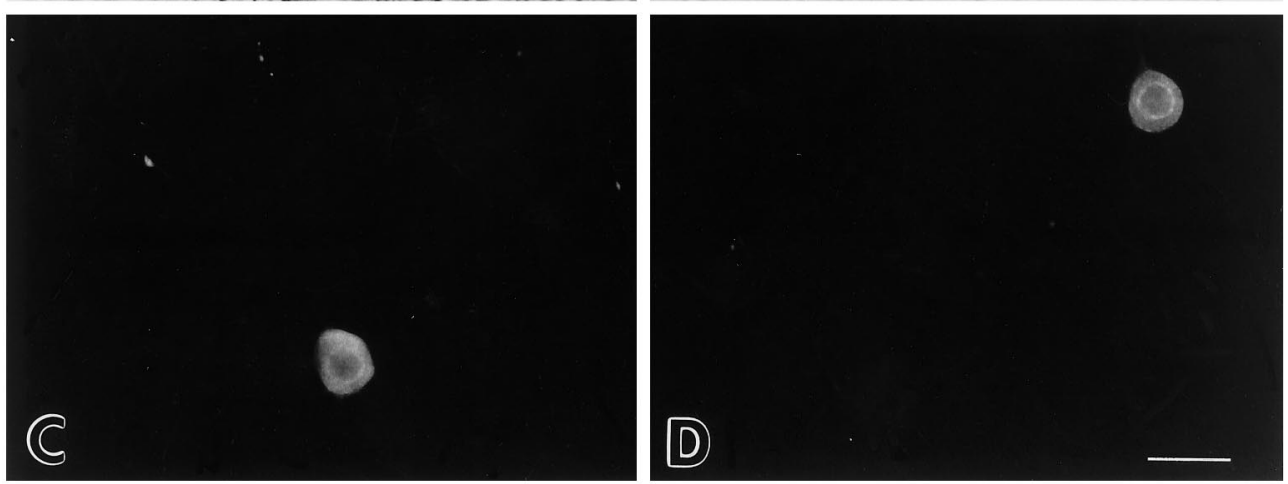

histochemical properties of the afferents (McMahon and Moore, 1988). In addition, cross-anastomosing cutaneous and muscle nerves in the hindlimb in adult rats alters substance $\mathrm{P}$ expression (McMahon and Gibson, 1987). The addition of a novel visceral target tissue in the path of a cutaneous nerve from the trigeminal ganglion increases the number of CGRP-IR fibers within that nerve (Horgan and van der Kooy, 1992). There is little information on a cellular level relating the fibers that interact with target to the number of neuronal perikarya that express neuropeptides in these studies. Target-derived factors may also affect the initial expression of neuronal phenotypes in the chick DRG in vitro. In DRG neurons cultured before the establishment of functional connections with target tissues, the addition of muscle, skin, brain, or spinal cord reduced the number of substance P-IR neurons (Barakat-Walter et al., 1991). NGF given to newborn rats stimulates a dose-dependent increase in substance P content in DRG in vivo (Otten et al., 1980) and in adult DRG cultures (Lindsay et al., 1989), but NGF does not seem to alter significantly the number of sensory neurons that express the peptide (Adler et al., 1984; Lindsay et al., 1989). In combination, these observations suggest that target-derived signals can influence some sensory phenotypic properties.

By contrast, the present study provides strong evidence for the early specification of mammalian sensory neurons to subsequently use CGRP or substance P or to express abundant neurofilament. Similarly, sympathetic neuroblasts cultured in the absence of target tissues develop appropriate proportions of neuropeptide Y-expressing neurons, with timing precisely like that in vivo (Hall and MacPhedran, 1995). These studies provide an important demonstration that multiple neuronal phenotypes in several peripheral ganglia can be temporally and spatially regulated in the absence of target tissues. Such early, target-independent development of neuronal phenotype has also been demonstrated in the avian retina (Yamagata and Sanes, 1995). Thus, although synaptic contacts in some systems can modify neuropeptide expression, they may do so on neurons that already possess the ability to regulate their own phenotype.

The present data suggest that the temporally and quantitatively appropriate initial expression of specific DRG neuronal phenotypes is unlikely to require target tissues. We assume that the neurons that express CGRP, substance P, and neurofilament in vitro are the same neurons that would express these phenotypes in vivo. This interpretation suggests that these neurons are specified as to neuropeptide before target contact. Mature neuronal function requires the matching of neurotransmitter and receptor at the synapse; such matching by prespecified neurons may be achieved by several means. Prespecified neurons could match with appropriate target through the growth of exuberant projections, followed by pruning of processes that contacted inappropriate targets. When one peripheral nerve is labeled in embryonic hindlimb, however, little label is detected in another nerve, suggesting that there is little branching of DRG afferents in the chick and rat (Honig, 1982; Payne et al., 1991; Mirnics and Koerber, 1995). Alternatively, neurons could send processes to various target tissues, and those that contacted inappropriate targets might be eliminated during the period of neuronal cell death. Although complete data do not exist, it seems that sensory fibers generally project correctly from the start. Another possibility is that prespecified neurons could precisely innervate appropriate target tissues. This hypothesis would predict that CGRP-IR axons that contact muscle and CGRP- and substance P-IR axons that contact skin would be segregated within appropriate nerves. Indeed, embryonic spinal nerves include bundles that remain fasciculated into the distal parts of the hindlimb, with a high degree of physical segregation (Honig, 1982; Mirnics and Koerber, 1995). Such segregated projection patterns do not necessarily mean that the sensory neurons are specified as to function, and additional studies are necessary to evaluate the phenotype of segregated axons. Finally, it is possible that although DRG neurons can express neuropeptides in the absence of target cues, interactions 


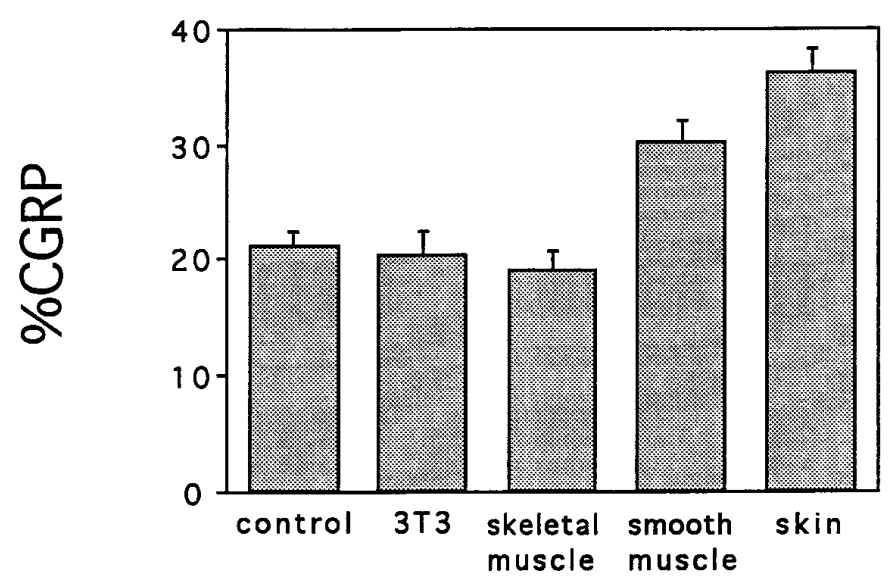

Figure 8. Co-culture with specific cells increased the number of CGRP-IR neurons. Dissociated E14.5 DRG neurons were co-cultured on collagen substrates with a monolayer of National Institutes of Health 3T3 cells, primary hindlimb skeletal muscle, a smooth muscle cell line, or a rat embryo skin cell line for $8 \mathrm{~d}$ in growth medium containing RS and 25 $\mathrm{ng} / \mathrm{ml}$ NGF. The cells were fixed and double-stained for CGRP and neuron-specific tubulin. The percentage of CGRP-IR neurons in each culture was determined in at least two coverslips/experiment in three to five experiments. The means are shown with error bars indicating the SEM. Neuronal survival in each condition was the same as control values on collagen, with the exception of neurons on smooth muscle, which had survival equal to $65 \%$ of control levels.

with target tissues could subsequently modify the initial pattern of neurotransmitter expression in sensory neurons. Whatever mechanisms allow for appropriate interactions with target tissue, the present study provides strong evidence that DRG neurons are specified early in embryogenesis, independent of their target tissues, and that physiologically appropriate target tissues such as skin can increase CGRP-IR-containing neurons above that intrinsic percentage.

\section{REFERENCES}

Adler JE, Kessler JA, Black IB (1984) Development and regulation of substance $P$ in sensory neurons in vitro. Dev Biol 102:417-425.

Barakat-Walter I, Affolter HU, Droz B (1991) Expression of substance P and preprotachykinin mRNA by primary sensory neurons in culture: regulation by factors present in peripheral and central target tissues. Mol Brain Res 10:107-114.

Boehmer CG, Norman J, Catton M, Fine LG, Mantyh PW (1989) High levels of mRNA coding for substance $\mathrm{P}$, somatostatin and $\alpha$ tubulin are expressed by rat and rabbit dorsal root ganglion neurons. Peptides 10:1179-1194.

Bothwell M (1995) Functional interactions of neurotrophins and neurotrophin receptors. Annu Rev Neurosci 18:223-253.

Christie GA (1962) Developmental stages in somite and post-somite rat embryos based on external appearance, and including some features of the macroscopic development of the oral cavity. J Morphol 114:263-286.

Coggeshall RE, Pover CM, Fitzgerald M (1994) Dorsal root ganglion cell death and surviving cell numbers in relation to the development of sensory innervation in the rat hindlimb. Dev Brain Res 82:193-212.

Crowley C, Spencer SD, Nishimura MC, Chen KS, Pitts-Meek S, Armanini MP, Ling LH, McMahon SB, Shelton DL, Levinson A, Phillips $\mathrm{H}$ (1994) Mice lacking nerve growth factor display perinatal loss of sensory and sympathetic neurons yet develop basal forebrain cholinergic neurons. Cell 76:1001-1011.

Davies AM (1994) The role of neurotrophins in the developing nervous system. J Neurobiol 25:1334-1348.

Fan G, Katz DM (1993) Non-neuronal cells inhibit catecholaminergic differentiation of primary sensory neurons: role of leukemia inhibitory factor. Development 118:83-93.

Fitzgerald M (1987) Prenatal growth of fine-diameter primary afferent into the rat spinal cord: a transganglionic study. J Comp Neurol 261:98-104.

Fitzgerald M (1991) A physiological study of the prenatal development of cutaneous sensory inputs to dorsal horn cells in the rat. J Physiol (Lond) 432:473-482.

Frank E, Westerfield M (1982) The formation of appropriate central and peripheral connections by foreign sensory neurones of the bullfrog. J Physiol (Lond) 324:495-505.

Gibbins IL, Furness JB, Costa M (1987) Pathway-specific patterns of the co-existence of substance $\mathrm{P}$, calcitonin gene related peptide, cholecystokinin and dynorphin in neurons of the dorsal root ganglia of the guinea-pig. Cell Tissue Res 248:417-437.

Gibson SJ, Polak JM, Bloom SR, Sabate IM, Mulderry PM, Gahtei MA, McGregor GP, Morrison JFB, Kelly JS, Evans RM, Rosenfeld MG (1984) Calcitonin gene-related peptide immunoreactivity in the spinal cord of man and of eight other species. J Neurosci 4:3101-3111.

Hall AK, MacPhedran SE (1995) Multiple mechanisms regulate sympathetic neuronal phenotype. Development 121:2361-2371.

Holzer P (1988) Local effector functions of capsaicin-sensitive sensory nerve endings: involvement of tachychinins, calcitonin gene related peptide and other neuropeptides. Neuroscience 24:739-768.

Honig MG (1982) The development of sensory projection patterns in embryonic chick hind limb. J Physiol (Lond) 330:175-202.

Horgan K, van der Kooy D (1992) Visceral targets specify calcitonin gene related peptide and substance $\mathrm{P}$ enrichment in trigeminal afferent projections. J Neurosci 12:1135-1143.

Hory-Lee F, Russell M, Lindsay RM, Frank E (1993) Neurotrophin 3 supports the survival of developing muscle in culture. Proc Natl Acad Sci USA 90:2613-2617.

Hunt SP, Rossi J (1985) Peptide- and non-peptide-containing unmyelinated primary afferents: the parallel processing of nociceptive information. Philos Trans R Soc Lond [Biol] 308:283-289.

Inaishi Y, Kashihara Y, Sakaguchi M, Nawa H, Kuno M (1992) Cooperative regulation of calcitonin gene related peptide levels in rat sensory neurons via their central and peripheral processes. J Neurosci 12:518-524.

Kai-Kai MA, Anderton BH, Keen P (1986) A quantitative analysis of the interrelationships between subpopulations of rat sensory neurons containing arginine vasopressin or oxytocin and those containing substance $\mathrm{P}$, fluoride resistant acid phosphatase or neurofilament protein. Neuroscience 18:475-486.

Kessler JA, Black IB (1980) Nerve growth factor stimulates the development of substance P in sensory ganglia. Proc Natl Acad Sci USA 77:649-652.

Kessler JA, Black IB (1981) Similarities in development of substance P and somatostatin in peripheral sensory neurons: effects of capsacin and nerve growth factor. Proc Natl Acad Sci USA 78:4644-4647.

Klein R, Silos-Santiago I, Smeyne RJ, Lira SA, Brambilla R, Bryant S, Zhang L, Snider WD, Barbacid M (1994) Disruption of the neurotrophin-3 receptor gene trkC eliminates 1a muscle afferents and results in abnormal movements. Nature 368:249-251.

Kopan R, Fuchs E (1989) A new look into an old problem: keratins as tools to investigate determination, morphogenesis and differentiation in skin. Genes Dev 3:1-15.

Kucera J, Walro JM, Reichler J (1988) Innervation of developing intrafusal muscle fibers in the rat. Am J Anat 183:344-358.

Kucera J, Walro JM, Reichler J (1989) Role of nerve and muscle factors in the development of rat muscle spindles. Am J Anat 186:144-160.

Kudo N, Yamada T (1985) Development of the monosynaptic stretch reflex in the rat: an in vitro study. J Physiol (Lond) 369:127-144.

Lawson SN, Waddell PJ (1991) Soma neurofilament immunoreactivity is related to cell size and fibre conduction velocity in rat primary sensory neurons. J Physiol (Lond) 435:41-63.

Lawson SN, Caddy KWT, Biscoe TJ (1974) Development of rat dorsal root ganglion neurones: studies of cell birthdays and changes in mean cell diameter. Cell Tissue Res 153:399-413.

Lawson SN, Harper AA, Harper EI, Garson JA, Anderton BH (1984) A monoclonal antibody against neurofilament protein specifically labels a subpopulation of rat sensory neurones. J Comp Neurol 228:263-272.

Lee Y, Takami K, Kawai Y, Girgis S, Hillyard CJ, MacIntyre I, Emson PC, Tohyama M (1985) Distribution of calcitonin gene related peptide in the rat peripheral nervous system with reference to its coexistence with substance P. Neuroscience 15:1227-1237.

Lembeck F, Gamse R (1982) Substance P in the nervous system, Vol 16. London: Pitman. 
Lindsay RM, Harmar AJ (1989) Nerve growth factor regulates expression of neuropeptide genes in adult sensory neurons. Nature 337:362-364.

Lindsay RM, Lockett C, Sternberg J, Winter J (1989) Neuropeptide expression in cultures of adult sensory neurons: modulation of substance $\mathrm{P}$ and calcitonin gene related peptide levels by nerve growth factor. Neuroscience 33:53-65.

Marti E, Gibson SJ, Polak JM, Facer P, Springall DR, Aswegen GV, Aitchson M, Koltzenburg M (1987) Ontogeny of peptide- and aminecontaining neurones in motor, sensory, and autonomic regions of rat and human spinal cord, dorsal root ganglia, and rat skin. J Comp Neurol 266:332-359.

McCarthy PW, Lawson SN (1989) Cell type and conduction velocity of rat primary sensory neurons with substance $\mathrm{P}$ like immunoreactivity. Neuroscience 28:745-753.

McCarthy PW, Lawson SN (1990) Cell type and conduction velocity of rat primary sensory neurons with calcitonin gene related peptide like immunoreactivity. Neuroscience 34:623-632.

McMahon SB, Gibson S (1987) Peptide expression is altered when afferent nerves reinnervate inappropriate tissue. Neurosci Lett 73:9-15.

McMahon SB, Moore CEG (1988) Plasticity of primary afferent acid phosphatase expression following rerouting of afferents from muscle to skin in the adult rat. J Comp Neurol 274:1-8.

McMahon SB, Armanini MP, Ling LH, Phillips HS (1994) Expression and coexpression of trk receptors in subpopulations of adult primary sensory neurons projecting to identified peripheral targets. Neuron 12:1161-1171.

Memberg SP, Hall AK (1995) Proliferation, differentiation, and survival of rat sensory neuron precursors in vitro require specific trophic factors. Mol Cell Neurosci 6:323-335.

Mirnics K, Koerber HR (1995) Prenatal development of rat primary afferent fibers: I. Peripheral projections. J Comp Neurol 355:589-600.

Molander C, Ygge J, Dalsgaard CJ (1987) Substance P-, somatostatinand calcitonin gene-related peptide-like immunoreactivity and fluoride resistant acid phosphatase- activity in relation to retrogradely labeled cutaneous, muscular and visceral primary sensory neurons in the rat. Neurosci Lett 74:37-42.

Nawa H, Patterson PH (1990) Separation and partial characterization of neuropeptide inducing factors in heart cell conditioned medium. Neuron 4:269-277.

Noguchi K, Senba E, Morita Y, Sato M, Tohyama M (1990) Coexpression of $\alpha$-CGRP and $\beta$-CGRP mRNAs in the rat dorsal root ganglion cells. Neurosci Lett 108:1-5.

O'Brien C, Woolf CJ, Fitzgerald M, Lindsay RM, Molander C (1989) Differences in the chemical expression of rat primary afferent neurons which innervate skin, muscle or joint. Neuroscience 32:493-502.

Otten U, Goedert M, Mayer N, Lembeck F (1980) Requirement of nerve growth factor for development of substance P-containing sensory neurones. Nature 287:158-159.

Patterson PH, Chun LLY (1974) The influence of non-neuronal cells on catecholamine and acetylcholine synthesis and accumulation in cultures of dissociated sympathetic neurons. Proc Natl Acad Sci USA 71:3607-3610.

Patterson PH, Nawa H (1993) Neuronal differentiation factors/cytokines and synaptic plasticity. Cell 72:123-137.

Payne J, Middleton J, Fitzgerald M (1991) The pattern and timing of cutaneous hair follicle innervation in the rat pup and human fetus. Dev Brain Res 61:173-182.

Perry MJ, Lawson SN, Robertson J (1991) Neurofilament immunoreactivity in populations of rat primary afferent neurons: a quantitative study of phosphorylated and non-phosphorylated subunits. J Neurocytol 20:746-758.

Reynolds ML, Fitzgerald M, Benowitz LI (1991) GAP-43 expression in developing cutaneous and muscle nerves in the rat hindlimb. Neuroscience 41:201-211.

Saito K (1979) Development of spinal reflexes in the rat fetus studies in vitro. J Physiol (Lond) 294:581-594.

Schecterson LC, Bothwell M (1992) Novel roles for neurotrophins are suggested by BDNF and NT3 mRNA expression in developing neurons. Neuron 9:449-463.

Schotzinger R, Landis SC (1994) Target determination of neurotransmitter phenotype in sympathetic neurons. J Neurobiol 25:620-639.

Scott SA (1992) Sensory neurons: diversity, development and plasticity. New York: Oxford UP.

Senba E, Shiosaka S, Hara Y, Inagaki S, Sakanaka M, Takatsuki K, Kawai Y, Tohyama M (1982) Ontogeny of the peptidergic system in the rat spinal cord: immunohistochemical analysis. J Comp Neurol 208:54-66.

Skofitsch G, Jacobowitz DM (1985) Calcitonin gene related peptide coexists with substance $\mathrm{P}$ in capsaicin sensitive neurons and sensory ganglia of the rat. Peptides 6:747-754.

Smeyne RJ, Klein R, Schnapp A, Long LK, Bryant S, Lewis A, Lira SA, Barbacid M (1994) Severe sensory and sympathetic neuropathies in mice carrying a disrupted Trk/NGF receptor gene. Nature 368:246-249.

Smith CL, Frank E (1987) Peripheral specifications of sensory neurons transplanted to novel locations along the neuraxis. J Neurosci 7:1537-1549.

Smith CL, Frank E (1988) Peripheral specification of sensory connections in the spinal cord. Brain Behav Evol 31:227-242.

Snider WD (1994) Functions of the neurotrophins during nervous system development: what the knockouts are teaching us. Cell 77:627-638.

Sun Y, Rao MS, Zigmond RE, Landis SC (1994) Regulation of vasoactive intestinal peptide expression in sympathetic neurons in culture and after axotomy: the role of cholinergic differentiation factor/leukemia inhibitory factor. J Neurobiol 25:415-430.

Tuchscherer MM, Seybold VS (1985) Immunohistochemical studies of substance P, cholecystokinin-octapeptide and somatostatin in dorsal root ganglia of the rat. Neuroscience 14:593-605.

Yamagata M, Sanes JR (1995) Target independent diversification and target specific projection of chemically defined retinal ganglion cell subsets. Development 121:3763-3776. 